\title{
BRCC3 wt Allele
}

National Cancer Institute

\section{Source}

National Cancer Institute. BRCC3 wt Allele. NCI Thesaurus. Code C124110.

Human BRCC3 wild-type allele is located in the vicinity of Xq28 and is approximately $52 \mathrm{~kb}$ in length. This allele, which encodes Lys-63-specific deubiquitinase BRCC36 protein, is involved in histone deubiquitination and DNA repair. 